\title{
Analisa Kepuasan Pengguna Website Layanan Akademik Kemahasiswaan (LYKAN) Menggunakan Metode Webqual 4.0
}

\author{
Ali Mustopa', Sarifah Agustiani², Siti Khotimatul Wildah ${ }^{3}$, Maysaroh $^{4}$ \\ 1,2,3,4 STMIK Nusa Mandiri \\ e-mail: ${ }^{1}$ alimustopa.aop@nusamandiri.ac.id, ${ }^{2}$ sarifah.sgu@nusamandiri.ac.id, ${ }^{3}$ siti.ska@nusamandiri.ac.id, \\ ${ }^{4}$ maysaro_maydihadi@yahoo.co.id

\begin{tabular}{ccc}
\hline Diterima & Direvisi & Disetujui \\
$10-01-2020$ & $12-02-2020$ & $17-02-2020$ \\
\hline
\end{tabular}

\begin{abstract}
Abstrak - Website merupakan layanan informasi bagi seluruh pengguna yang dapat diakses tanpa batas. Penggunaan website juga banyak digunakan seperti pada dunia pendidikan. Salah satu penerapan website pada dunia pendidikan diterapkan pada kampus Universitas Bina Sarana Informatika yang memberikan layanan website kepada mahasiswa berupa Layanan Akademik Kemahasiswaan (LYKAN). Website LYKAN digunakan sebagai wadah informasi mahasiswa berupa data prestasi, penelitian dan sarana konseling dengan dosen pembimbing akademik. Namun, untuk mencapai hasil website yang lebih baik kedepannya diperlukan sebuah pengembangan dari segi informasi maupun layanan sehingga menghasilkan kualiatas website yang sesuai dengan kebutuhan mahasiswa. Dalam penelitian ini, kualitas dari website LYKAN diukur dengan menggunakan metode Webqual 4.0 sebagai tolak ukur pengembangan sistem dari website tersebut yang didalamnya terdapat variabel yang mencangkup penilaian pada kualitas kegunaan, kualitas informasi dan kualitas interaksi. Dalam menentukan hasil dari ketiga varibel tersebut, digunakan Chi Square Test untuk mengetahui pengaruh variabel tersebut terhadap kepuasan pengguna website. Sumber data penelitian ini diperoleh dari hasil olahan kuesioner yang berasal dari kelas 13.3C.01 dengan jumlah mahasiswa 42 orang dan pengambilan sampel sebanyak 38 responden. Dari penelitian yang dilakukan menggunakan chi square test menghasilkan keputusan bahwa nilai uji menunjukkan $\mathrm{X}^{2}$ sebesar 47,76 sedangkan derajat kebebasan bernilai sebesar 15,07 yang artinya $\mathrm{H}_{\mathrm{a}}$ diterima dan $\mathrm{H}_{0}$ ditolak. Hasil tersebut menunjukkan bahwa kualitas kegunaan, informasi dan interaksi layanan memiliki pengaruh terhadap kepuasan pengguna website Layanan Akademik Kemahasiswaan (LYKAN).
\end{abstract}

Kata Kunci: Website, LYKAN, Webqual, Chi Square Test, Kepuasan pengguna

Abstract - Website is an information service for all users that can be accessed indefinitely. Use of the website is also widely used as in education. One of the implementation of website in education is applied on campus of Bina Sarana Informatics University that provide website services to students in the form of student academic services (LYKAN). LYKAN Website is used as a student information facility in the form of achievement data, research and counseling facilities with academic guidance lecturers. However, to achieve better results of the website in the future is required a development in terms of information and services so as to produce a website that suits the needs of students. In this research, the quality of LYKAN website is measured using Webqual 4.0 method as the benchmark of system development from the website in which there are variables that cover the assessment on quality of usability, quality Information and quality of interactions. In determining the outcome of the three varibells, used Chi Square Test to know the influence of the variable to the satisfaction of the website user. The source of this research data was obtained from the results of the processed questionnaire derived from the class $13.3 \mathrm{C}$. 01 with a student number of 42 people and sampling as many as 38 respondents. From research conducted using Chi Square test resulted in a decision that the test value shows X2 amounting to 47.76 while the degree of freedom of value of 15.07 meaning Ha accepted and $\mathrm{HO}$ rejected. These results indicate that quality of usability, information and service interactions have an influence on the satisfaction of users of the Student Academic Services website (LYKAN).

Keyword: Website, LYKAN, Webqual, Chi Square Test, User satisfaction

\section{PENDAHULUAN}

Website merupakan penyedia informasi yang lengkap dan telah menjadi salah satu aspek penting dalam berbagai bidang terutama pendidikan karena dapat diakses dengan mudah dan tanpa batasan (Monalisa, 2016). Hal inilah yang membuat website semakin dikembangkan dalam berbagai bidang seperti organisasi dan instansi pemerintah terutama pendidikan (Pamungkas et al., 2019).

Penggunaan website pada bidang pendidikan sudah diterapkan oleh kampus Universitas Bina Sarana Informatika berupa website students.bsi.ac.id 
sebagai wadah informasi untuk para mahasiswa, dosen maupun masyarakat luas. Pelayanan website tentunya didukung dengan banyak fitur sebagai informasi seperti data mahasiswa, kegiatan akademik, pembayaran, nilai, bahkan layanan akademik kemahasiwaan.

Layanan Akademik Kemahasiswan (LYKAN) merupakan wadah informasi bagi para mahasiswa untuk pendataan data mahasiswa berupa informasi akademik, prestasi, penelitian dan wadah konseling dengan dosen pembimbing akademik pada kampus Universitas Bina Sarana Informatika. Website yang saat ini digunakan tentunya akan selalu membutuhkan pengembangan sistem sesuai dengan kebutuhan para penggunanaya terutama mahasiswa.

Sebagai salah satu penunjang dalam pengembangan website LYKAN maka dilakukan sebuah penelian mengenai kepuasan mahasiswa terhadap website tersebut dengan cara membagikan kuesioner kepada mahasiswa sebagai responden. Responden yang digunakan dalam penelian ini adalah mahasiswa kelas 13.3C.01 dengan jumlah mahasiswa sebanyak 42 orang dan pengambilan sampel sebanyak 38 responden.

Terdapat berbagai cara maupun metode untuk mencari hubungan kualitas layanan website dengan kepuasan penggunanya, salah satunya adalah Webqual. Pengukuran kualitas pada sebuah website menggunakan metode webqual 4.0 dilakukan oleh para pengguna web sebagai tolak ukur untuk mengetahui bagaimana pengelola web menyesuaikan persepsi pengguna (Hapsari \& Priyadi, 2017). Selain itu penggunaan metode webqual telah digunakan dalam beberapa penelitian dan terbukti hasil analisis menggunakan metode webqual berpengaruh pada kualitas layanan terhadap suatu website.

Metode WebQual ini digunakan dengan tujuan untuk mengetahui tingkat kepuasan pengguna, karena teknik pengukuran metode WebQual dilakukan berdasarkan persepsi pengguna akhir yang diukur dengan beberapa instrumen penelitian yang dikategorikan dalam tiga variabel yaitu penggunaan (usability), kualitas informasi (information quality), dan kualitas interaksi (services interaction) (Abbas, 2013).

Penelitian serupa telah banyak dilakukan oleh peneiti sebelumnya, yang membahas tentang kualitas website dengan metode yang sama yaitu Webqual yaitu penelitian yang dilakukan oleh (Manik et al., 2017) mengenai seberapa besar metode webqual 4.0 berpengaruh terhadap kepuasan pengguna website. Hasil penelitiannya membuktikan bahwa semua variabel dalam metode webqual ini sangat berpengaruh dalam menganalisis kepuasan pengguna website. Penelitian selanjutnya dilakukan oleh (Monalisa, 2016) yang menganalisa kepuasaan mahasiswa terhadap kualitas layanan website dengan menggunakan metode webqual. Hasil penelitiannya membuktikan bahwa kualitas layanan website sangat berpengaruh terhadap kepuasan mahasiswa dengan kata lain metode webqual ini sangat berpengaruh dalam mengalisis kepuasan pengguna terhadap kualitas website. Penelitian selanjutnya di lakukan oleh (Abbas, 2013) mengenai analisis kepuasa terhadap website Universitas Negeri Yogyakarta. Metode yang yang digunakan dalam penelitian ini adalah metode WebQual dan metode Chi Square. Hasil dari penelitian ini membuktikan bahwa dimensi usability, information quality, dan service interactio mempengaruhi tingkat kepuasan mahasiswa terhadap kualitas website UNY . Penelitian lainnya adalah penelitian yang dilakukan oleh (Syaifullah \& Soemantri, 2016) menggunakan metode webqual 4.0 untuk melakukan pengukurqan terhadap kualitas website. Hasil dari penelitian ini membuktikan bahwa kepuasan pengguna sangat dipengaruhi oleh semua variable Webqual 4.0.

Dengan demikian metode yang digunakan daam penelitian ini tidak hanya metode webqual tetapi didukung dengan pengujian chi square. Uji chi-square merupakan jenis uji yang menggunakan skala data ordinal yang dilakukan pada dua variabel, di mana skala data kedua variabel adalah nominal (Negara \& Prabowo, 2018), uji chi square ini digunakan untuk membuktikan apakah terdapat hubungan antara variabel yang terdapat pada metode webqual dengan kepuasan pengguna terhadap website LYKAN sehingga menghasilkan data yang dibutuhkan untuk acuan pengembangan website.

Dalam pengujian chi square terdapat beberapa pengujian yaitu uji validitas merupakan pengujian yang mengukur sejauh mana ketepatan suatu instrumen pengukuran (tes) dalam melakukan pengukurannya. Suatu tes akan dinyatakan memiliki validitas yang tinggi apabila alat tersebut menjalankan fungsi ukur secara tepat atau memberikan hasil ukur yang sesuai dengan maksud dilakukannya terhadap pengukuran tersebut. Artinya hasil ukur pengukuran tersebut merupakan besaran yang mencerminkan secara tepat fakta atau keadaan sesungguhnya dari apa yang diukur (Syaifullah \& Soemantri, 2016). Selain itu ada uji reabilitas yang merupakan pengujian yang mengukur sejauh mana hasil suatu pengukuran dapat dipercaya. Suatu hasil pengukuran dapat dipercaya apabila dalam beberapa kali pelaksanaan pengukuran menghasilkan nilai yang realtif sama, selama aspek yang diukur dalam diri subyek memang belum berubah (Syaifullah \& Soemantri, 2016). menyatakan bahwa reliabilitas ukuran menyangkut seberapa jauh skor deviasi individu, atau skor-z, relative konsisten apabila dilakukan pengulangan pengadministrasian dengan tes yang sama atau tes yang ekivalen (Syaifullah \& Soemantri, 2016). 


\section{METODE PENELITIAN}

Metode penelitian yang dilakukan dalam penelitian ini terdiri dari 3 bagian, diantaranya observasi, kuisioner, dan studi pustaka. Metode observasi ini merupakan tahapan pertama dari penelitian yang bertujuan untuk melakukan pengamatan terhadap responden yang akan diteliti yaitu mahasiswa UBSI, dalam hal ini responden yang digunakan hanya sebagian dari keseluruhan mahasiswa UBSI yaitu kelas 13.3C.01 berjumlah 42 mahasiswa dengan pengambilan sampel sebanyak 38 responden. Selanjutnya pengamatan dilakukan dengan membagikan link kuesioner berupa google form kepada para responden, yang didalamnya terdapat beberapa daftar pernyataan yang wajib diisi oleh responden, kemudian hasil kuisioner tersebut dianalisis sebagai bahan untuk penelitian. Didukung dengan metode studi pustaka yang dilakukan dengan cara mempelajari dan melihat buku-buku, jurnal-jurnal maupun materi lainnya sebagai penunjang materi yang erat kaitannya dengan pembahasan untuk selanjutnya dijadikan sebagai landasan teori. Sedangkan metode analisis data yang pada penulisan ini adalah metode Webqual dan Chi Square Test.

\section{HASIL DAN PEMBAHASAN}

\section{Objek Penelitian}

Objek penelitian yang digunakan pada penelitian ini merupakan website Layanan Akademik Kemahasiswaan atau biasa disebut dengan LYKAN. Website ini berfungsi sebagai perantara komunikasi antara dosen dan mahasiswa mengenai berbagai layanan informasi seperti prestasi, penelitian dan konseling.

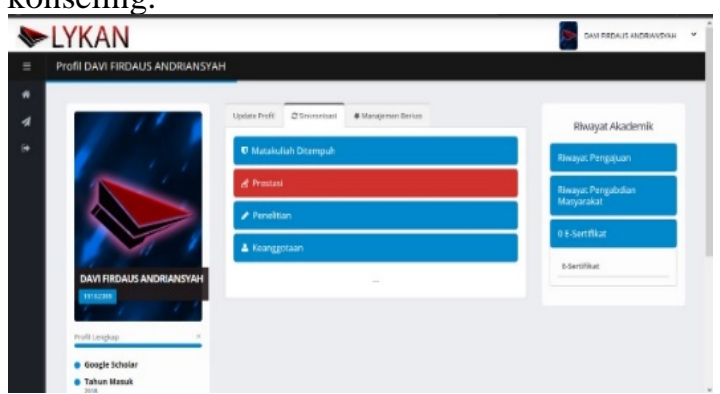

Sumber: http://lykan.bsi.ac.id

Gambar 1. Tampilan website LYKAN

\section{Menentukan Jumlah Sampel}

Sampel merupakan bagian dari jumlah atau karakteristik yang dimiliki oleh suatu populasi. Untuk itu sampel yang diambil dari populasi benarbenar mewakili suatu objek penelitian. Teknik sampling yang digunakan dalam penelitian ini adalah simple random sampling yaitu teknik pengambilan sampel dari populasi dilakukan secara acak. Untuk menentukan jumlah sampel dipilih menggunakan rumus slovin untuk menghitung ukuran sampel (Hekhmatyar \& Supriyadi, 2017), berikut rumusnya:

$$
\begin{aligned}
\mathbf{n} & =\frac{\boldsymbol{N}}{1+\boldsymbol{N}(\boldsymbol{e})^{2}} \\
\mathrm{n} & =\frac{42}{1+42(0,05)^{2}} \\
\mathrm{n} & =\frac{42}{1,105}=38,09 \text { dibulatkan menjadi } 38
\end{aligned}
$$

Di mana:

$\mathrm{n}$ : ukuran sampel

$\mathrm{N}$ : populasi

e : tingkat ketepatan (presisi) 5\% $(0,05)$

Berdasarkan hasil perhitungan rumus diatas, maka sampel yang digunakan dalam penelitian ini adalah 38 pengguna pada kelas 13.3C.01 yang menggunakan website Layanan Akademik Kemahasiswaan (LYKAN) Universitas Bina Sarana informatika.

\section{Instrumen Penelitian}

Menurut (Riduwan, 2015), “Instrumen penelitian digunakan untuk mengukur nilai variabel yang akan diteliti. Jumlah instrumen yang digunakan tergantung pada jumlah variabel yang akan diteliti”.

Instrumen digunakan untuk mengukur nilai variabel yang akan diteliti. Adapun variabel yang digunakan adalah variabel kemudahan penggunaan, kualitas informasi, dan kualitas interaksi website LYKAN Universitas Bina Sarana Informatika.

Berikut indikator dari variabel-variabel penelitian yang digunakan sebagai penyataan kuesioner:

Tabel 2. Instrumen Penelitian

\begin{tabular}{|c|c|}
\hline Var & $\tan$ \\
\hline $\begin{array}{l}\text { Kemudahe } \\
\text { Pengguna } \\
\text { (X1) }\end{array}$ & 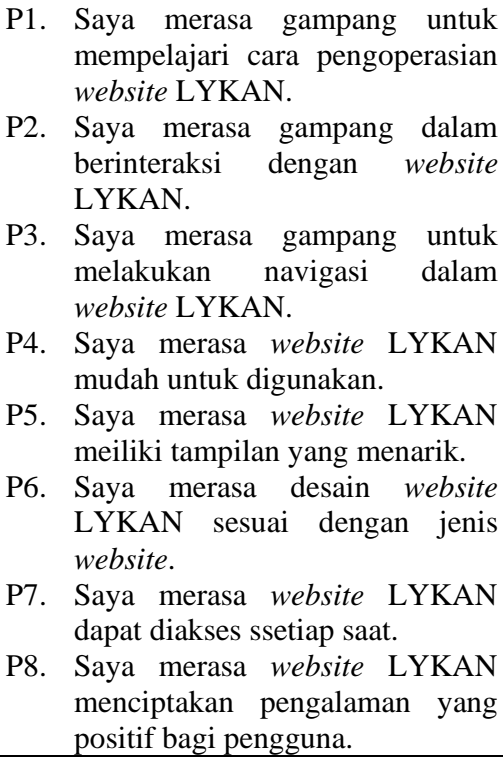 \\
\hline $\begin{array}{l}\text { Kualitas } \\
\text { Informasi } \\
\text { (X2) }\end{array}$ & $\begin{array}{l}\text { P9. Website LYKAN menyediakan } \\
\text { informasi yang akurat. } \\
\text { P10. Website LYKAN menyediakan } \\
\text { informasi yang dapat dipercaya. } \\
\text { P11. Website LYKAN menyediakan } \\
\text { informasi yang up to date. } \\
\text { P12. Website LYKAN menyediakan } \\
\text { informasi yang relevan. } \\
\text { P13. Website LYKAN menyediakan } \\
\text { kemudahan dalam memahami } \\
\text { informasi. }\end{array}$ \\
\hline
\end{tabular}




\begin{tabular}{|c|c|}
\hline & $\begin{array}{l}\text { P14. Website LYKAN menyediakan } \\
\text { informasi yang sesuai dengan } \\
\text { detail yang tepat. } \\
\text { P15. Website LYKAN menyediakan } \\
\text { informasi yang sesuai dengan } \\
\text { format yang tepat. }\end{array}$ \\
\hline $\begin{array}{l}\text { Kuali } \\
\text { Intera } \\
\text { (X3) }\end{array}$ & $\begin{array}{l}\text { P16. Website LYKAN memiliki } \\
\text { reputasi yang baik. } \\
\text { P17. Saya merasa aman untuk } \\
\text { melakukan interaksi dengan } \\
\text { website LYKAN. } \\
\text { P18. Saya merasa informasi personal } \\
\text { aman pada website LYKAN. } \\
\text { P19. Website LYKAN memberikan } \\
\text { ruang untuk personalisasi. } \\
\text { P20. Website LYKAN memberikan } \\
\text { ruang untuk komunitas. } \\
\text { P21. Website LYKAN memberikan } \\
\text { kemudahan untuk berkomunikasi } \\
\text { dengan organisasi/pengguna lain. }\end{array}$ \\
\hline \multicolumn{2}{|c|}{$\begin{array}{l}\text { Sumber : Hasil Penelitian (2020) } \\
\text { Hasil kuesioner berupa data akan disimpan } \\
\text { dalam format Excel dan langsung digunakan sebagai } \\
\text { data mentah untuk analisa dengan software SPSS. } \\
\text { Pada penelitian ini terdapat empat variabel yang } \\
\text { digunakan yaitu kualitas kegunaan (X1), kualitas } \\
\text { informasi (X2) dan kualitas interaksi (X3) } \\
\text { Pilihan jawaban dari kuesioner bisa dibuat } \\
\text { sesuai pada pendapat responden dengan pernyataan } \\
\text { yang diberikan. Setiap pernyataan dapat berupa } \\
\text { pendapat positif dan pendapat negatif. Indikator } \\
\text { untuk jawaban responden bisa dibuat dengan } 5 \text { untuk } \\
\text { Sangat Setuju (SS), } 4 \text { untuk Setuju (S), } 3 \text { untuk } \\
\text { Cukup Setuju (CS), } 2 \text { untuk Tidak Setuju (TS) dan } \\
1 \text { untuk Sangat Tidak Setuju (STS). Hal ini berlaku } \\
\text { kebalikannya untuk pernyataan negatif. } \\
\text { Dalam pengukuran skala likert, variabel yang } \\
\text { ditentukan harus dijabarkan terlebih dahulu menjadi } \\
\text { beberapa bagian indikator dan sub indikator yang } \\
\text { digunakan untuk menyusun pernyataan terhadap } \\
\text { responden. Adapun pernyataan yang dapat } \\
\text { digunakan dalam skala likert terdiri dari dua jenis, } \\
\text { yaitu pernyataan positif dan pernyataan negatif dan } \\
\text { setiap pernyataan tersebut diberi nilai (score). }\end{array}$} \\
\hline
\end{tabular}

\section{Uji Validitas}

Uji validitas ini digunakan untuk memperoleh data yang valid atau sesuai dengan penelitian yang digunakan. Dalam pengujian ini prinsip yang digunakan adalah mengkorelasikan masing-masing nilai skor pada setiap variabel dengan nilai skor total variabel. Berikut merupakan hasil uji validitas terhadap setiap variabel:
Tabel 3. Uji Validitas Kualitas Kegunaan

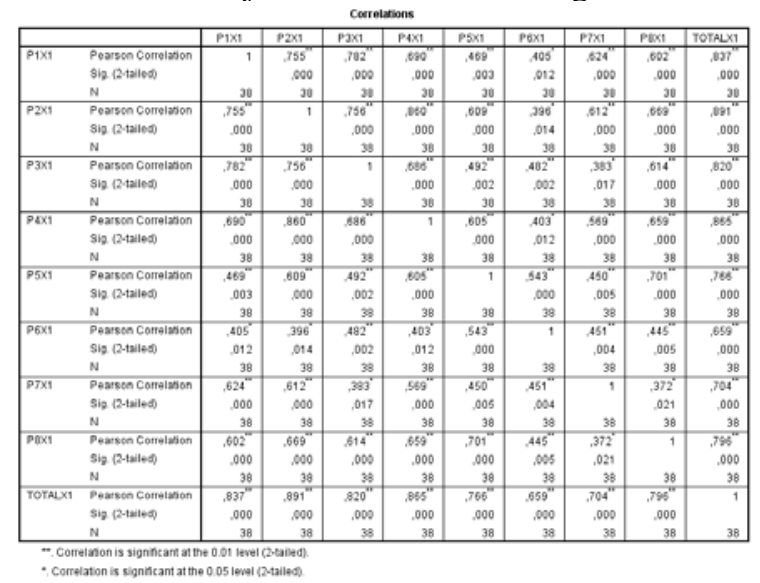

Sumber: Hasil Penelitian (2020)

Tabel 4. Hasil pengujian kualitas keggunaan

\begin{tabular}{|c|c|c|}
\hline Pertanyaan & r Tabel & r Hitung \\
\hline P1X1 & 0,320 & $0,837^{* *}$ \\
\hline P2X1 & 0,320 & $0,891^{* *}$ \\
\hline P3X1 & 0,320 & $0,820^{* *}$ \\
\hline P4X1 & 0,320 & $0,865^{* *}$ \\
\hline P5X1 & 0,320 & $0,766^{* *}$ \\
\hline P6X1 & 0,320 & $0,659^{* *}$ \\
\hline P7X1 & 0,320 & $0,704^{* *}$ \\
\hline P8X1 & 0,320 & $0,796^{* *}$ \\
\hline
\end{tabular}

Sumber: Hasil Penelitian (2020)

Tabel 5. Uji Validitas Kualitas Informasi

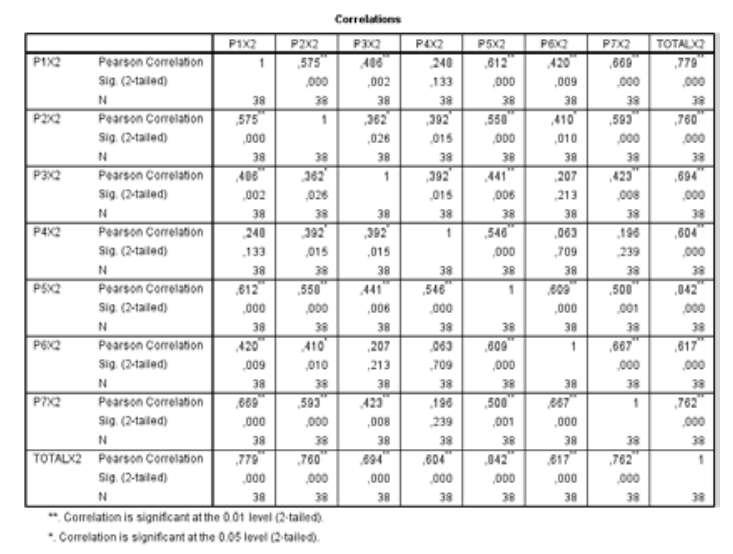

Sumber: Hasil Penelitian (2020)

Tabel 6. Hasil Validitas Kualitas Informasi

\begin{tabular}{|c|c|c|}
\hline Pertanyaan & r Tabel & r Hitung \\
\hline P1X2 & 0,320 & $0,799^{* *}$ \\
\hline P2X2 & 0,320 & $0,760^{* *}$ \\
\hline P3X2 & 0,320 & $0,694^{* *}$ \\
\hline P4X2 & 0,320 & $0,604^{* *}$ \\
\hline P5X2 & 0,320 & $0,842^{* *}$ \\
\hline P6X2 & 0,320 & $0,617^{* *}$ \\
\hline P7X2 & 0,320 & $0,762^{* *}$ \\
\hline
\end{tabular}

Sumber: Hasil Penelitian (2020) 
Tabel 7. Uji Validitas Kualitas Interaksi

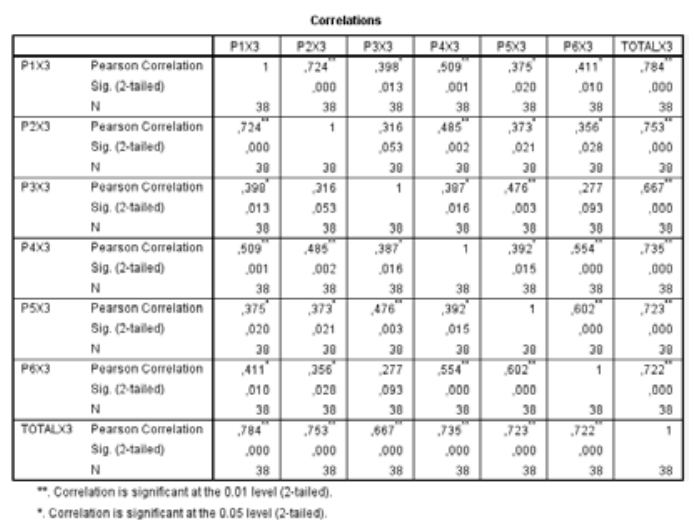

Sumber: Hasil Penelitian (2020)

Tabel 8. Hasil Validitas Kualitas Interaksi

\begin{tabular}{|c|c|c|}
\hline Pertanyaan & r Tabel & r Hitung \\
\hline P1X3 & 0,320 & $0,784^{* *}$ \\
\hline P2X3 & 0,320 & $0,753^{* *}$ \\
\hline P3X3 & 0,320 & $0,667^{* *}$ \\
\hline P4X3 & 0,320 & $0,753^{* *}$ \\
\hline P5X3 & 0,320 & $0,723^{* *}$ \\
\hline P6X3 & 0,320 & $0,722^{* *}$ \\
\hline
\end{tabular}

Sumber: Hasil Penelitian (2020)

\section{Uji Releabilitas}

Hasil penelitian akan dikatakan reliabel, jika instrumen yang digunakan untuk pengujian obyek yang sama akan menghasilkan data yang sama dengan kondisi waktu yang berbeda (Sugiyono, 2014).

Uji reliabilitas digunakan untuk melihat sejauh mana instrumen pengukuran menunjukan derajat keakuratan, ketepatan, dan ketelitiannya. Pengujian ini dilakukan dengan menggunakan metode internal consistency. Sedangkan koefisien Cronbach Alpha digunalan untuk mengukur internal consistency. Ketentuan pengambilan keputusan yang digunakan adalah:

a. Suatu variabel akan dikatakan berstatus reliabel jika memiliki nilai Alpha >0,60.

b. Suatu variabel dapat dikatakan tidak berstatus reliabel jika memiliki nilai Alpha < 0,60

Berdasarkan hasil uji reliabilitas tersaji dalam Gambar 2.

\begin{tabular}{|r|r|r|}
\multicolumn{2}{c|}{ Kualitas Kegunaan } & \multicolumn{2}{c|}{ Kualitas Informasi } \\
\hline $\begin{array}{c}\text { Cronbach's } \\
\text { Alpha }\end{array}$ & N of Items \\
\hline 914 & 8 \\
\hline
\end{tabular} \begin{tabular}{|r|r|r|}
$\begin{array}{c}\text { Cronbach's } \\
\text { Alpha }\end{array}$ & N of Items \\
\hline
\end{tabular}

Kualitas Interaksi

\begin{tabular}{|r|r|}
\hline $\begin{array}{c}\text { Cronbach's } \\
\text { Alpha }\end{array}$ & N of Items \\
\hline 817 & 6 \\
\hline
\end{tabular}

Sumber: Hasil Penelitian (2020)

Gambar 2. Hasil Uji Releabilitas SPSS

\section{Metode Pengukuran Tingkat Kepuasan Pengguna}

Penilaian kepuasan dan loyalitas pengguna terhadap website LYKAN diperoleh dari hasil olahan kuesioner yang dirancang berdasarkan tinstrumen atau dimensi yang ada pada metode WebQual dengan menggunakan skala likert sebagai acuan pengukurannya. Skala pengukuran Tabel 10 .

Tabel 9. Bobot Nilai Jawaban Responden

\begin{tabular}{|l|c|}
\hline \multicolumn{1}{|c|}{ JAWABAN } & SKOR \\
\hline Sangat Memuaskan & 5 \\
\hline Memuaskan & 4 \\
\hline Cukup Memuaskan & 3 \\
\hline Kurang Memuaskan & 2 \\
\hline Tidak Memuaskan & 1 \\
\hline
\end{tabular}

Sumber: (Putra et al., 2014)

Menurut (Putra, Sholeh, \& Widyastuti, 2014) skala Likert digunakan untuk mengetahui interval penilaian skala numerik. Hasil perhitungan interval penilaian skala Likert dapat dilihat pada Tabel 11 Rumus :

$R S=\frac{m-n}{b}$

Keterangan :

Rs Rentang Skala

M Angka tertinggi dalam pengukuran

N Angka terendah dalam pengukuran

b Banyaknya kelas atau kategori yang dibentuk

Tabel 10. Interval Penilaian Skala Likert

\begin{tabular}{|l|c|c|}
\hline Sangat Memuaskan & SM & $4,2 \leqq \mathrm{x} \leqq 5$ \\
\hline Memuaskan & M & $3,4 \leqq \mathrm{x}<4,2$ \\
\hline Cukup Memuaskan & CM & $2,6 \leqq \mathrm{x}<3,4$ \\
\hline Kurang Memuaskan & KM & $1,8 \leqq \mathrm{x}<2,6$ \\
\hline Tidak Memuaskan & TM & $1 \leqq \mathrm{x}<1,8$ \\
\hline
\end{tabular}

Sumber: (Putra et al., 2014)

Dari tabel interval penilaian skala likert dapat dianalisa perhitungan tingkat kepuasan responden sebagai berikut:

Skor Jawaban Jumlah total dari setiap variabel Total Skor Skor penilaian $\left(\mathrm{SM}^{* 5}\right)+(\mathrm{M} * 4)$ $+\left(\mathrm{CM}^{*} 3\right)+\left(\mathrm{KM}^{*} 2\right)+\left(\mathrm{TM}^{*} 1\right)$

Skor Rata- Total Skor dibagi dengan Rata jumlah responden

Interpretasi Diambil dari Skor Rata-Rata kemudian lihat tingkat interpretasinya pada Tabel 11

Tabel 11. Perhitungan Tingkat Kepuasan Responden

\begin{tabular}{|c|c|c|c|c|c|c|c|c|c|}
\hline \multirow{2}{*}{ No } & \multirow{2}{*}{ VAR } & \multicolumn{5}{|c|}{ SKOR JAWABAN } & \multirow[b]{2}{*}{ TS } & \multirow{2}{*}{ SR } & \multirow[b]{2}{*}{ I } \\
\hline & & SM & $\mathbf{M}$ & CM & KM & TM & & & \\
\hline \multicolumn{10}{|c|}{ USABILITY QUALITY } \\
\hline 1 & P1 & 12 & 14 & 11 & 1 & 0 & 151 & 3,97 & $\mathrm{M}$ \\
\hline 2 & P2 & 9 & 18 & 8 & 3 & 0 & 147 & 3,87 & $\mathrm{M}$ \\
\hline 3 & P3 & 11 & 17 & 8 & 1 & 1 & 150 & 3,95 & $\mathrm{M}$ \\
\hline 4 & $\mathrm{P} 4$ & 10 & 13 & 12 & 2 & 1 & 143 & 3,76 & $M$ \\
\hline 5 & P5 & 9 & 15 & 12 & 2 & 0 & 145 & 3,82 & $\mathrm{M}$ \\
\hline 6 & P6 & 9 & 15 & 12 & 0 & 2 & 143 & 3,76 & $\mathrm{M}$ \\
\hline 7 & P7 & 13 & 15 & 9 & 0 & 1 & 153 & 4,03 & $\mathrm{M}$ \\
\hline 8 & P8 & 10 & 14 & 12 & 2 & 0 & 146 & 3,84 & $\mathrm{M}$ \\
\hline \multicolumn{2}{|c|}{ TOTAL } & 83 & 121 & 84 & 11 & 5 & 1178 & 31,00 & $\mathrm{M}$ \\
\hline
\end{tabular}




\begin{tabular}{|c|c|c|c|c|c|c|c|c|c|}
\hline \multicolumn{10}{|c|}{ INFORMATION QUALITY } \\
\hline 9 & P9 & 11 & 20 & 5 & 2 & 0 & 154 & 4,05 & $\mathrm{M}$ \\
\hline 10 & P10 & 7 & 23 & 6 & 1 & 1 & 148 & 3,89 & $\mathrm{M}$ \\
\hline 11 & P11 & 10 & 21 & 4 & 0 & 3 & 149 & 3,92 & $\mathrm{M}$ \\
\hline 12 & P12 & 9 & 22 & 4 & 1 & 2 & 149 & 3,92 & M \\
\hline 13 & P13 & 9 & 24 & 3 & 1 & 1 & 153 & 4,03 & $\mathrm{M}$ \\
\hline 14 & P14 & 13 & 19 & 6 & 0 & 0 & 159 & 4,18 & $\mathrm{M}$ \\
\hline 15 & P15 & 11 & 22 & 5 & 0 & 0 & 158 & 4,16 & $\mathrm{M}$ \\
\hline \multicolumn{2}{|c|}{ TOTAL } & 70 & 151 & 33 & 5 & 7 & 1070 & 28,16 & M \\
\hline \multicolumn{10}{|c|}{ INTERACTION QUALITY } \\
\hline 16 & P16 & 8 & 13 & 14 & 3 & 0 & 140 & 3,68 & $\bar{M}$ \\
\hline 17 & P17 & 6 & 17 & 10 & 3 & 2 & 136 & 3,58 & $\mathrm{M}$ \\
\hline 18 & P18 & 5 & 14 & 14 & 2 & 3 & 130 & 3,42 & M \\
\hline 19 & P19 & 3 & 25 & 9 & 0 & 1 & 143 & 3,76 & $\mathrm{M}$ \\
\hline 20 & P20 & 3 & 19 & 14 & 1 & 1 & 136 & 3,58 & $\mathrm{M}$ \\
\hline 21 & P21 & 8 & 15 & 13 & 0 & 2 & 141 & 3,71 & $\mathrm{M}$ \\
\hline \multicolumn{2}{|c|}{ TOTAL } & 33 & 103 & 74 & 9 & 9 & 826 & 21,74 & $\mathrm{M}$ \\
\hline
\end{tabular}

Sumber : Hasil Penelitian (2020)

Dari tabel 11 terlihat bahwa rata-rata skor jawaban responden paling banyak memilih diantara rentang 3-5 dengan interprestasi "Memuaskan", nilai interval paling tinggi sebesar 4,18 untuk variable yang diukur berupa memberikan informasi secara detail. Adapun nilai interval terendah sebesar 3,42 untuk variable yang diukur berupa informasi pribadi tersimpan dengan aman, namun walaupun memiliki interval terendah masih dalam kategori interprestasi "Memuaskan”.

\section{Pengujian Chi Square / Kai Kuadrat}

Pengujian Chi Square digunakan untuk menguji hipotesis atau dugaan awal pada suatu penelitian yang dapat dilakukan dengan rumus berikut:

$x^{2}=a \frac{f 0-f h^{2}}{f h}$

Keterangan :

$x^{2}=$ Nilai Chi Square

$f o=$ Frekuensi yang diperoleh dari populasi atau sample yang diamati

$f h=$ Frekuensi harapan dalam sampel yang diperoleh dari frekuensi harapan dalam populasi.

Frekuensi yang diharapkan $(f h)$ dapat diperoleh dengan:

$f h=\frac{\text { Total Baris }}{N}$ yaitu:

Hipotesis yang akan diuji dalam penelitian ini

H0 Tidak adanya hubungan antara dimensi kualitas kegunaan, informasi, dan interaksi terhadap kepuasan pengguna pada website LYKAN

Ha Adanya hubungan antara dimensi kualitas kegunaan, informasi, dan interaksi terhadap kepuasan pengguna pada website LYKAN

Taraf signifikan yang akan digunakan sebesar $\mathrm{a}=5 \%$ (0.05) dan derajat kebebasan untuk distribusi Chi Square adalah:

$\mathrm{Db}=($ Baris-1) $($ Kolom-1)
$\mathrm{Db}=(5-1)(3-1)$

Wilayah Kritis pada X2 Tabel $=$ X2 $(\mathrm{a} ; \mathrm{Db})=(0.05$; 8 ) $=15,507$ (nilai ini dilihat dari titik persentase distribusi chi square)

Tabel 12. Frekuensi Observasi (F0)

\begin{tabular}{|l|c|c|c|c|c|c|}
\hline \multicolumn{1}{|c|}{ DIMENSI } & SM & $\mathbf{M}$ & $\begin{array}{c}\mathbf{C} \\
\mathbf{M}\end{array}$ & $\begin{array}{c}\mathbf{K} \\
\mathbf{M}\end{array}$ & $\begin{array}{c}\mathbf{T} \\
\mathbf{M}\end{array}$ & JML \\
\hline X1 & 83 & $\begin{array}{c}12 \\
1\end{array}$ & 84 & 11 & 5 & 304 \\
\hline $\mathbf{X 2}$ & 70 & $\begin{array}{c}15 \\
1\end{array}$ & 33 & 5 & 7 & 266 \\
\hline X3 & 33 & $\begin{array}{c}10 \\
3\end{array}$ & 74 & 9 & 9 & 228 \\
\hline JUMLAH & $\mathbf{1 8 6}$ & $\begin{array}{c}\mathbf{3 7} \\
\mathbf{5}\end{array}$ & $\mathbf{1 9 1}$ & $\mathbf{2 5}$ & $\mathbf{2 1}$ & $\mathbf{7 9 8}$ \\
\hline
\end{tabular}

Sumber : Hasil Penelitian (2020)

Tabel 13. Frekuensi Harapan (Fh)

\begin{tabular}{|l|c|c|c|}
\hline \multicolumn{4}{|c|}{ FREKUENSI HARAPAN } \\
\hline & $\mathbf{X 1}$ & $\mathbf{X 2}$ & $\mathbf{X 3}$ \\
\hline FH SM & 70,86 & 62,00 & 53,14 \\
\hline FH M & 142,86 & 125,00 & 107,14 \\
\hline FH CM & 72,76 & 63,67 & 54,57 \\
\hline FH KM & 9,52 & 8,33 & 7,14 \\
\hline FH TM & 8,00 & 7,00 & 6,00 \\
\hline
\end{tabular}

Sumber : Hasil Penelitian (2020)

Tabel 14. Frekuensi Harapan (Fh)

\begin{tabular}{|c|c|c|c|c|c|c|}
\hline VAR & SKOR & F0 & FH & F0-FH & $\begin{array}{l}\text { (F0- } \\
\text { FH)2 }\end{array}$ & $\begin{array}{c}\text { (F0- } \\
\text { FH)2/FH }\end{array}$ \\
\hline \multirow{5}{*}{ X1 } & SM & 83,00 & 70,86 & 12,14 & 147,38 & 2,08 \\
\hline & $\mathbf{M}$ & 121,00 & 142,86 & 21,86 & 477,86 & 3,34 \\
\hline & CM & 84,00 & 72,76 & 11,24 & 126,34 & 1,74 \\
\hline & KM & 11,00 & 9,52 & 1,48 & 2,19 & 0,23 \\
\hline & TM & 5,00 & 8,00 & $-3,00$ & 9,00 & 1,13 \\
\hline & & & & & & 8,52 \\
\hline \multirow{6}{*}{$\mathrm{X} 2$} & SM & 70 & 62,00 & 8,00 & 64,00 & 1,03 \\
\hline & M & 151 & 125,00 & 26,00 & 676,00 & 5,41 \\
\hline & CM & 33 & 63,67 & 30,67 & 940,65 & 14,77 \\
\hline & KM & 5 & 8,33 & $-3,33$ & 11,09 & 1,33 \\
\hline & TM & 7 & 7,00 & 0,00 & 0,00 & 0,00 \\
\hline & & & & & & 22,55 \\
\hline \multirow{6}{*}{ X3 } & SM & 33 & 53,14 & $20,14^{-}$ & 405,62 & 7,63 \\
\hline & M & 103 & 107,14 & $-4,14$ & 17,14 & 0,16 \\
\hline & CM & 74 & 54,57 & 19,43 & 377,52 & 6,92 \\
\hline & $\mathbf{K M}$ & 9 & 7,14 & 1,86 & 3,46 & 0,48 \\
\hline & TM & 9 & 6,00 & 3,00 & 9,00 & 1,50 \\
\hline & & & & & & 16,70 \\
\hline \multicolumn{6}{|c|}{ NILAI CHI SQUARE } & 47,76 \\
\hline
\end{tabular}

Sumber : Hasil Penelitian (2020)

Dari hasil tabel tersebut menunjukan nilai X2 hitung sebesar 47,76 sedangkan derajat kebebasan adalah 15,507 hal ini menunjukan Ha diterima sedangkan Ho ditolak yang artinya terdapat pengaruh antara dimensi kegunaan, dimensi informasi dan dimensi interaksi terhadap kepuasan pengguna pada website LYKAN. 


\section{KESIMPULAN}

Hasil perhitungan yang diperoleh dari olahan data kuisioner responden dapat dinyatakan bahwa perhitungan interval paling tinggi adalah sebesar 4,18 sedangkan nilai interval terendah sebesar 3,42 yang artinya kualitas website LYKAN berada dalam kategori MEMUASKAN karena kedua nilai tersebut berada dalam rentang interpretasi "MEMUASKAN". Begitupun dengan hasil perhitungan chi square terhadap tiga dimensi penilaian webqual mulai dari kualitas kegunaan, kualitas informasi dan kualitas interaksi menghasilkan nilai chi square sebesar 47,76 dengan derajat kebebasan 15.507, artinya secara keseluruhan website LYKAN telah dinilai memuaskan terutama pada dimensi interaksi dan informasi yang memiliki nilai sebesar 16,70 dan 22,55. Sedangkan dimensi kegunaan memiliki nilai sebesar 8,52. Dalam hal ini, dimensi kegunaan menghasilkan nilai terendah daripada dimensi lainnya sehingga pengembangan website LYKAN harus lebih ditekankan pada aspek kegunaannya.

Hasil yang diperoleh dari penilaian pengguna maupun perhitungan chi square ini dapat dijadikan sebagai bahan evaluasi bagi para pengembang website dan referensi bagi penelitian selanjutnya, diharapkan penelitian ini akan terus dilanjutkan dengan menggunakan metode yang berbeda untuk melihat metode mana yang menghasilkan nilai yang lebih akurat. Sehingga pengembangan website dapat dilakukan seiring dengan perkembangan penelitian namun tetap sesuai dengan persepsi dan kebutuhan penggunanya.

\section{REFERENSI}

Abbas, W. (2013). Analisa Kepuasan Mahasiswa Terhadap Website Universitas Negeri Yogyakarta (UNY). Prosiding SNST Ke-4, F1. 1-6.

Hapsari, K., \& Priyadi, Y. (2017). Perancangan Model Data Flow Diagram Untuk Mengukur Kualitas Website Menggunakan Webqual 4.0. JURNAL SISTEM INFORMASI BISNIS, 7(1), 66. https://doi.org/10.21456/vol7iss1pp66-72

Hekhmatyar, O. G., \& Supriyadi, D. (2017). Measurement Satisfaction Information System Quality Service On BSI Using Webqual And CSI. 2(2), 2-7.
Manik, A., Salamah, I., \& Susanti, E. (2017). PENGGUNA WEBSITE POLITEKNIK NEGERI SRIWIJAYA THE IMPACT OF WEBQUAL 4 . 0 METHOD TOWARDS USER. 477-484.

Monalisa, S. (2016). Analisis Kualitas Layanan Website Terhadap Kepuasan Mahasiswa dengan Penerapan Metode Webqual ( Studi Kasus: UIN Suska Riau ). Jurnal Sains, Teknologi Dan Industri, ISSN 2407-0939, 13(2), 181-189.

Negara, I. C., \& Prabowo, A. (2018). PENGGUNAAN UJI CHI - SQUARE UNTUK MENGETAHUI PENGARUH TINGKAT PENDIDIKAN DAN UMUR TERHADAP PENGETAHUAN PENASUN MENGENAI HIV - AIDS DI PROVINSI DKI JAKARTA Igo Cahya Negara Agung Prabowo Jurusan Matematika , FMIPA Universitas Jenderal Soedirman , Purwokert. Prosiding Seminar Nasional Matematika Dan Terapannya 2018

Pamungkas, R. A., Alfarishi, E., Aditiarna, E., Muklhisin, A., Faticha, R., \& Aziza, A. (2019). Analisis Kualitas Website SMK Negeri 2 Sragen dengan Metode Webqual 4 . 0 dan Importance Performance Analysist ( IPA ). 3(1), 17-23. https://doi.org/10.30865/mib.v3i1.1009

Putra, Z. F. S., Sholeh, M., \& Widyastuti, N. (2014). Analisis Kualitas Layanan Website BTKPDIY Menggunakan Metode Webqual 4.0. Jurnal SCRIPT. Institut Sains \& Teknologi AKPRIND Yogyakarta., 2(1).

Riduwan. (2015). Belajar Mudah Penelitian. Alfabet.

Sugiyono. (2014). Metode Penelitian Pendidikan Pendekatan Kuantitatif, Kualitatif, dan R\&D. Alfabeta.

Syaifullah, \& Soemantri, D. O. (2016). PENGUKURAN KUALITAS WEBSITE MENGGUNAKAN METODE WEBQUAL 4 . 0. Jurnal Rekayasa Dan Manajemen Sistem Informasi, 2(1). 